KAIROS ELT JOURNAL, Vol. 1, No. 3, December 2017

Copyright@2017, ISSN: 2580-4278

\title{
IMPROVING STUDENTS' SKILL IN WRITING RECOUNT TEXTS BY USING PEER REVIEW STRATEGY TO THE EIGHTH GRADE STUDENTS OF SMP KATOLIK BUDI MURNI 3 MEDAN
}

\author{
Mariana Naiborhu, Karisma E. Tarigan, Novalina Sembiring \\ Catholic University of Saint Thomas
}

\begin{abstract}
The aim of this study is to improve students' skill in writing recount texts and to find out the students' responses after being taught by using Peer Review Strategy. The subject of the study is the students of Class VIII A of SMP Budi Murni 3 Medan in the Academic Year of 2017/2018. Questionnaire, observation sheet, field notes, and writing tests were used as the instruments for collecting data. The results of the study showed the significant improvement of the students' skill in writing recount texts. It is proven by the students' mean score of each test: pre-test is 64,68 , formative test is 70,75 and post-test is 75,86 . The progress is about 11,18 based on the students' mean score. Moreover, the improvement could also be seen from the Minimum Mastery Criteria (Kriteria Ketuntasan Minimum (KKM)) which showed that the students' score of pre-test is $20,68 \%$, formative test is $58,62 \%$, and post-test is $72,41 \%$. It can be concluded that there is a significant progress of $52 \%$ based on (Kriteria Ketuntasan Minimum (KKM)). The students also agreed with the application of Peer Review Strategy in writing recount texts. It can be seen from the result of questionnaire that there was $60 \%$ of strongly agree and $40 \%$ of agree. Therefore, the application of Peer Review Strategy is very suitable to improve students' skill in writing recount texts.
\end{abstract}

Keywords: writing skill, recount texts, peer review strategy

\section{INTRODUCTION}

In the process of teaching and learning English, writing is one of English skills that must be learnt in formal school. Not only for academic but also for life itself such as science, technology, culture and so on. Writing is the most difficult skill for mastering. It is difficult for students to understand writing subject because it is really different from Indonesian. They cannot write English correctly because there are so many aspects that must be understood such as the organization, content, mechanics etc. It makes them lazy and bored when they are asked to write English.

Teaching writing skill cannot be ignored because it is one of the ways to improve students' knowledge and also as basic skill to communicate with others in written form. By writing, students can share their ideas and express their feeling and experiences on paper. However, learning writing is difficult enough because students should write English correctly by paying attention to the structure, vocabulary, word formation, and the other aspects such as spelling, capitalization, punctuation. In junior high school, the students should also know how to write English texts such as descriptive, recount, narrative etc. In this study, the writer focuses on recount texts because dealing with writing skill at eighth grade junior high school curriculum, in the basic competence the students should be able to arrange oral and written recount text, short and simple about activities, events regarding with social function, text structure and appropriate linguistic elements. Therefore, the students must be able to write English text especially recount texts because it is necessity for academic.

However, based on the writer's experience at Teaching Practice Program 2016 of SMP Katolik Budi Murni 3 Jln. Merapi No. 2 Medan, it is difficult for some students to write recount

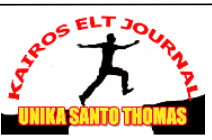


texts. First, they are confused to express and develop their idea in writing recount texts because they lack of vocabulary. For example, when they wanted to write a recount texts, some of them do not know what the English word for pengalaman, mengganggu, mencari etc. It is difficult for them because they must open dictionary continuously. Second, they have difficulties in writing recount texts based on generic structure include of orientation, event, and reorientation. For example, some of them cannot distinguish which one as orientation, events and re-orientation. Third, they are confused about the grammar and to use tenses of recount text. For example, some of them cannot understand about simple past tense and they are confused to use it. Last, they are confused to arrange a good sentence in past tense form. Some of them cannot arrange sentence based on S-V-O/C. Furthermore, they cannot write English text correctly especially recount texts. By the condition above, the writer concludes that the students' skill in writing recount texts is still low.

Based on the explanation above, the writer solve the students' problems by using new strategy. There are some strategies in teaching writing skill namely using series picture, clustering, revising, peer review and so on. The writer considers Peer Review Strategy is a suitable strategy to improve students' skill in writing recount texts. The writer chose this strategy because based on Breuch (2004:1) states that Peer Review is an instructional writing activity in which students read and provide commentary on one another's writing to help students improve their writing. This strategy is an active learning strategy in enhancing the process of improving English writing skill and allows them to improve their work before it is graded. It is also supported by some relevant studies conducted in improving students' skill in writing recount texts.

The first study had been done by Nasution (2012) entitled "Improving Students' Writing Recount Achievement Through Peer Review Technique of SMA Negeri 21 Medan". Nasution states that the result of her study showed that students' writing scores in recount text after applying Peer Review Technique from pre-test to post-test improved. It is proved by the data, which showed that the students' mean score of post-test (81.4) is higher than formative test (73.8) and also than pre-test (59.7). The second study had been done by Arifiana (2015) entitled 'Improving Students' Skill in Writing Recount Texts by Using Peer Review Technique of the Eighth Grade of SMP 4 Batang, Central Java". Arifiana states that the students' mean score from pre-test to formative test improved from 63.00 to 74.29 and the next improvement showed by the students' mean score of formative test to post test, which is 74.29 to 79.50 .

Both cycles showed good result and positive progress which indicated that Peer Review Technique improved the students' skill in writing recount texts at eighth grade students at SMP Negeri 4 Batang. It can be concluded Peer Review Strategy is an effective strategy which can improve students' skill in writing recount texts. Based on the background in this study, the writer conducts a study entitled "Improving Students' Skill in Writing Recount Texts by Using Peer Review Strategy to the Eighth Grade Students of SMP Katolik Budi Murni 3 Medan”.

\section{REVIEW OF LITERATURE Writing}

Writing is a productive skill of the English language which needs to be mastered by the students in learning English because they need it for academic purpose. Meyers (2005:2) states that writing is an action, a process of discovering and organizing our ideas, putting them on paper, reshaping and revising them. It means writing is an activity to write something on paper.

Meanwhile, Graham and Perin (2007:9) state that writing is a skill that draws on the use of strategies (such as planning, evaluating, and revising text) to accomplish a variety of goals, such as writing a report or expressing an opinion with the support of evidence. Writing is a process of expressing ideas, feelings on paper which is started by planning, drafting, evaluating and revising in order to tell and inform someone about something. 
KAIROS ELT JOURNAL, Vol. 1, No. 3, December 2017

Copyright@2017, ISSN: 2580-4278

Therefore, to write correctly, the students should have good ability in writing process so that readers are interested in reading their writing and understand the messages clearly. This is in line with Harmer (2004:3) who states that being able to write is a vital skill for speakers of a foreign language as much as for everyone using their own first language. It means that writing is an important skill because it is also the basic skill for stsudents to communicate with others in written form.

\section{Components of Writing}

Writing has some components which can make a good writing. To produce it, a writer has to pay attention on all components of writing. The components of writing based on Brown (2004: 244-245) are:

1) Organization

It consists of introduction, body, and conclusion. It is about how the writer makes a good relationship between the titles, introductory paragraph, and the topic, the body of paragraph, generalisation, and conclusion. It is about whether all of the components above are support each other and composed orderly by the writer or not.

2) Content

Content is about logical development of ideas. The ideas concrete and thoroughly developed or not, whether the essay addressed the issue or not, is there any extraneous material present or not in the text.

3) Grammar

It is about all the rules language application used by the writer. For example, native like fluency English grammar, correctness of using relative clause, prepositions, modals, articles, verb forms and tense sequencing.

4) Mechanics

It is about the punctuation, spelling, and all of the graphic convention of the language. It is about correctly using English writing conventions; all needed capitals, paragraph intended, using comma, full-stop.

5) Vocabulary

It is about style and quality of expression, how the writer uses precise vocabulary, parallel structures, and word choosing.

From the explanation, it can be concluded that in the process of writing, students should pay attention to all components of writing such as organization, content, grammar, mechanics and vocabulary in order to produce good writing.

\section{Teaching Writing}

Teaching writing at junior high school is difficult enough because based on the curriculum teaching writing at that level, the teacher must teach English based on the genre in teaching learning process such as descriptive, narrative, recount, etc. Dealing with teaching writing based on the genre, Hyland (2003:98) says that writing based on genres is not just writing but a writer writes something to achieve some purpose. Therefore, students must be able to follow certain social convention for organizing their messages or ideas in order to recognize readers of the purposes of the writer. Related to teaching writing, Harmer (2007:3839) proposes some strategies which can be considered by teachers in dealing with the teaching writing:

1) The way the teacher gets students to plan

Before starting to write, the teacher may support students to think about what they want to write. The teacher can help students in building their knowledge before they start writing.

2) The way the teacher encourages students to draft, reflect, and revise

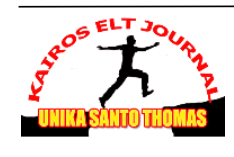


KAIROS ELT JOURNAL, Vol. 1, No. 3, December 2017

Copyright@2017, ISSN: 2580-4278

The teacher can involve students to collaborative writing activity as it allows students to draft, reflect, and revise. This way enables students to respond to other students' writing.

3) The way the teacher responds to students' writing

At this point, the teacher can help students by giving suggestions to students' draft.

Teacher's suggestion can be very useful to make some betterment in students' writing.

In addition, Hyland (2003:99) says that teaching writing is not only about planning and making a course but it needs some orientations based on the aspects of writing in each organizing the writing teaching. The orientations on teaching are focusing on language structures, text functions, theme, creative expression, composing process, content and genre.

By teaching writing well, students can make good use of writing, as part of an integrate skills approach to language learning. However, to teach writing, the teacher must have appropriate strategy in order to make the students able to write well. As usual, the students will enjoy if they are working together, in pairs or small groups, and involve talking as well as writing because they can get the opportunity to express themselves imaginatively (Byrne, 1988:43).

\section{Genre}

According to Gerot and Wignell (1994:192) "a genre can be defined as a culturally specific text-type which result from using language (written or spoken) to helps accomplish something". Meanwhile, Harmer (2007:113) states that genre is a type of writing which members of discourse community would instantly recognize for what it is. It means that genre is form of writing which has function to tell something with some variations in written. Therefore, students should be able to understand the concept and to identify the kind of texts of their writing.

\section{Kinds of Genre}

According to Gerot and Wignell (1994:192), there are fourteen types of genre text namely recount, news item, anecdote, spoof, explanation, procedure, report, analytical exposition, hortatory exposition, discussion, description, review, narrative and commentary.

\section{Recount Texts}

Recount text is one of texts taught to the eighth grade students. Gerot and Wignell (1994:194) say that recount text is a text to retell events for the purpose of informing or entertaining. In addition, Emilia (2011: 74) also states that recount text is a text which retell event or experiences in the past. It means that by writing recount text, students can retell their experience in written form to inform and entertain the readers. However, to write recount text correctly, the students should know the role or parts of writing in the form of recount texts. follows:

Hyland (2004:135) states that there are three generic structure of recount text, as

1) Orientation: provides the setting and produces participants. It provides information about who, where, and when.

2) Record of Events: tell what happened, present event in temporal sequence. It usually recounted in chronological order. Personal comments and/ or evaluative remarks, which are interspersed throughout the record of events.

3) Re-orientation: optional-closure of events. It is 'rounds off' the sequence of events.

Whereas, the grammatical features of recount texts are:

1) Use of nouns and pronouns to identify people, animals, things involved

2) Use of actions verbs to refer to events 
KAIROS ELT JOURNAL, Vol. 1, No. 3, December 2017

Copyright@2017, ISSN: 2580-4278

3) Use of past tense to locate events in relation to speaker or writers' time

4) Use of conjunctions and time connectives to sequence of events

5) Use of adverb and adverbial phrase to indicate place and time

6) Use of adjective to describe nouns

\section{Peer Review Strategy}

Peer Review is one of strategies in teaching writing. It is an essential tool in writing process. Breuch (2004:149) states that Peer Review is an exercise in which students review each other' written work and connected to revision part of the writing process in which writers refine and make substantive changes to their written work. Lundstrom and Baker (in Pearce et al, 2009:5) state that Peer Review is also referred to peer assessment, peer evaluation, peer response, or peer editing. Peer Review Strategy is an activity in process of students' writing to respond to each other' writing and it is also the process approach to teach writing.

Meanwhile, Liu and Hansen (2002:1) state that in Peer Review activities, students work together to provide feedback on one another's writing in both written and oral through active engagement with each other's progress over multiple drafts, have become a common feature of writing instruction. It means that Peer Review Strategy is a teaching writing strategy which can build self-confidence and students' accuracy of their own writing. This is in line with Breuch (2004:145) who states that Peer Review supports process writing with a focus on drafting and revision and enables students to get multiple feedback (e.g., from teacher, peer, and self) across various drafts.

According to Liu and Hansen (2005:31) "Peer Review is an interaction which involves students to exchange information". It means that Peer Review Strategy involve students' interaction with others in learning process. Clark (in Godlee \& Jefferson, 2003:229) also states that Peer Review is constructive and offers suggestions and feedback in the spirit of intellectual collaboration.

Therefore, in teaching learning writing, students will work in pair of student group to improve their writing by giving revising or correction on others' paper. However, the students have roles and responsibilities in commenting and critiquing on other writing in both written and oral formats in the process of writing. Breuch (2004:149) states that to conduct Peer Review, students simply exchange written work with other students, read the work, and provide comments to help the writer improve their writing and see how others have approached their work, and they can practice being part of a writing community. It means that Peer Review Strategy can be conducted in pairs of student group and each student exchange his paper with his partner. The two students then read each other's papers and discuss where the papers could be improved.

\section{The Procedures of Peer Review Strategy}

Peer Review Strategy is a teaching writing strategy which allows and encourages students to take an active role in managing their own learning. Pearce, et al, (2009:4) say that Peer Review requires students to analyse, review, clarify and correct each other's work. Before conducting peer review, there are three things which are needed to understand by writers based on Breuch (2004:149-150):

1) Roles in Peer Review

Peer Review consists of two or more people. There are two roles in applying Peer Review namely as a writer and as a reviewer. Writer and reviewer have opportunity to discuss ideas for revision. The reviewer reads through the writers' paper and then ask question to writer for further clarification.

2) Appropriate Dialogue Strategies 
KAIROS ELT JOURNAL, Vol. 1, No. 3, December 2017

Copyright@2017, ISSN: 2580-4278

Reviewers should be prepared to provide positive comments that helpstudentsimprove their writing. During a Peer Review, the reviewer might ask questions of the authorfor clarification on the paper. Questions could be about content, context, audience, purpose, organization, support, design, or expression.

3) Suggestions for Constructive Criticism

A reviewer may often feel awkward making comments about another student's paper, particularly if the reviewer finds something that needs to be improved. Reviewers should keep in mind that Peer Review Strategy is the opportunity to provide constructive criticism, not negative feedback.

Edge (2009:48) emphasizes that there are some strategies to conduct Peer Review Strategy:

1) Teacher needs to divide class up into pairs of student group

2) Each students has brought their own paper

3) The teacher makes sure that the students are working, but does not interrupt their work

4) The teacher moves round the class and makes notes of important mistakes These can be corrected with the whole class later

5) When doing an exercise with separate items in it, students can try to correct each other

6) When doing a peer review, one of the students can sometimes act as an observer to note mistakes for discussion

\section{RESEARCH METHOD}

The design of this study is Classroom Action Research (CAR). The data of this study are quantitative and qualitative data. The quantitative data were collected by using written test, in the form of essay. While the qualitative data were collected by using observation sheet, field notes and questionnaire.

This study also involved four phases in each cycle which are essential as proposed by Kemmis and Mc Taggart (1988:11). Those phases are planning, acting, observing, and reflecting. Each cycle has three meetings. The action that the writer did in the first cycle influenced the second cycle because it was needed to improve what was missing in the first cycle. It made the writer prepare everything which was needed in the second cycle so that the learning teaching process could work better than before. The process in action research which was shown in the following scheme was taken from Kemmis and McTaggart (1988: 11).

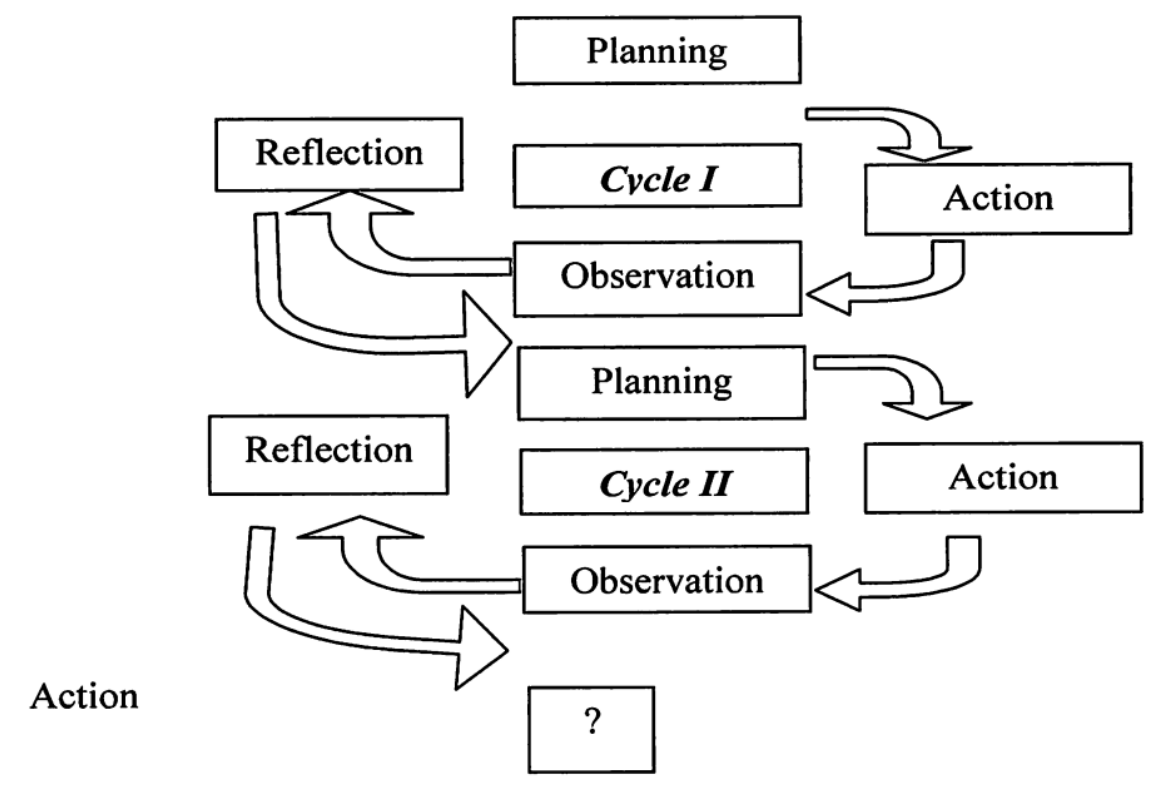

Figure 3.1: Scheme of Action Research by Kemmis and McTaggart (1988:11)

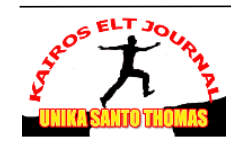


KAIROS ELT JOURNAL, Vol. 1, No. 3, December 2017

Copyright@2017, ISSN: 2580-4278

\section{DATA ANALYSIS}

Data Analysis

The data in this study were collected by quantitative and qualitative data. The quantitative data were taken from the students' writing score which collected through pre-test, formative test and post-test in both of cycle. The qualitative data were taken from observation sheet, field notes and questionnaire which described an event that occurred while conducting study. Every cycle was conducted in four meetings. Pre-test was done in the first meeting and formative test at the end of cycle I in the last meeting. The second cycle was also conducted in four meetings including post-test. The data analysis showed the process of improving students' skill in writing recount texts by using Peer Review Strategy and the improvement of the students' writing score.

\section{The Quantitative Data}

The quantitative data was taken from the test result of students, namely pre-test before treatment, formative test after cycle one, and post-test after the end of cycle two. The complete result of the students' score in every test can be seen from the table and the histogram of score interval and the frequency.

\section{Students' Pre-Test Score}

\section{Table 4.1: Pre-Test Score Interval}

\begin{tabular}{lll}
\hline Score Interval & Frequency & Percentage \\
\hline $\mathbf{3 0 - 3 8}$ & 1 & $3 \%$ \\
\hline $\mathbf{3 9 - 4 7}$ & 1 & $3 \%$ \\
\hline $\mathbf{4 8 - 5 6}$ & 5 & $17 \%$ \\
\hline $\mathbf{5 7 - 6 5}$ & 8 & $28 \%$ \\
\hline $\mathbf{6 6 - 7 4}$ & 8 & $28 \%$ \\
\hline $\mathbf{7 5 - 8 3}$ & 4 & $14 \%$ \\
\hline $\mathbf{8 4 - 9 2}$ & 2 & $7 \%$ \\
\hline $\mathbf{9 3 - 1 0 0}$ & 0 & $0 \%$ \\
\hline TOTAL & $\mathbf{2 9}$ & $\mathbf{1 0 0 \%}$
\end{tabular}

Scoring interval is found by applying this following formula:

Scoring Interval $(\mathrm{P})=\frac{X n-X 1}{1+3,3 \log n}$

Where:

The division of distance $(\mathrm{R})=\mathrm{Xn}$ (the highest score) $-\mathrm{X} 1$ (the lowest score) $\quad$ In which, Xn $=84$ and $\mathrm{X} 1=30$

The sum of whole data $(K)=1+3,3 \log n$ $\mathrm{N}=$ The number of data, $\log 29=$ 1,46 So, $\mathrm{P}=\frac{84-30}{1+3,3 \log 29}=\frac{54}{1+4,81}=\frac{54}{5,81}=9$

From the table of pre-test score interval and frequency above, the writer presented the data in histogram. 
KAIROS ELT JOURNAL, Vol. 1, No. 3, December 2017

Copyright $\odot 2017$, ISSN: 2580-4278

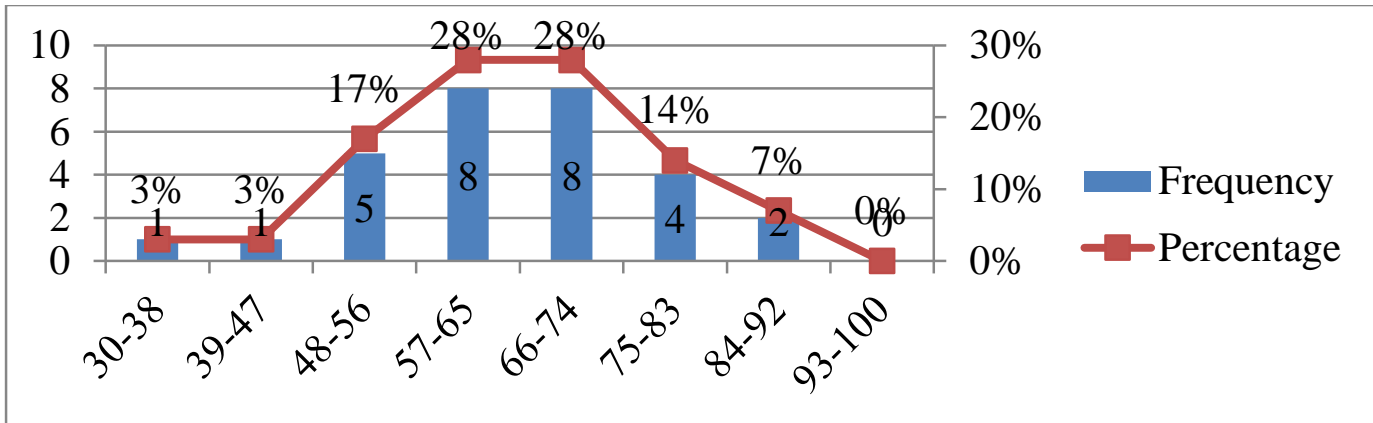

Figure 4.1: The Histogram of Pre-Test Score

From the histogram of pre-test, the highest score interval was 66 to $74(28 \%)$. It meant that there were 8 students got the highest score in interval 66 to 74 . The lowest score interval was 93 to 100, there was no student who got pre-test score in this interval. There was (3\%) 1 student who got score pre-test in each interval 30 to 38 and 39 to 47 . Then, there were (17\%) 5 students who got score pre-test in interval 48 to 56 . There were $(28 \%) 8$ students who got score pre-test in interval 57 to 65 . There were (14\%) 4 students who got score pre-test in interval 75 to 83 . There were (7\%) 2 students who got score pre-test in interval 84 to 92 .

\section{Students' Formative Test Score}

Table 4.2 : Formative Test Score Interval

\begin{tabular}{lll}
\hline Score Interval & Frequency & Percentage \\
\hline $\mathbf{4 2 - 4 8}$ & 2 & $7 \%$ \\
\hline $\mathbf{4 9 - 5 5}$ & 0 & $0 \%$ \\
\hline $\mathbf{5 6 - 6 2}$ & 4 & $14 \%$ \\
\hline $\mathbf{6 3 - 6 9}$ & 5 & $17 \%$ \\
\hline $\mathbf{7 0 - 7 6}$ & 9 & $31 \%$ \\
\hline $\mathbf{7 7 - 8 3}$ & 7 & $24 \%$ \\
\hline $\mathbf{8 4 - 9 0}$ & 2 & $7 \%$ \\
\hline $\mathbf{9 1 - 9 7}$ & 0 & $0 \%$ \\
\hline $\mathbf{9 8 - 1 0 0}$ & 0 & $0 \%$ \\
\hline Total & $\mathbf{2 9}$ & $\mathbf{1 0 0 \%}$ \\
\hline
\end{tabular}

Scoring interval is found by applying this following formula:

Scoring Interval $(P)=\frac{X n-X 1}{1+3,3 \log n}$

Where:

The division of distance $(\mathrm{R})=\mathrm{Xn}$ (the highest score) $-\mathrm{X} 1$ (the lowest score) In which, Xn $=84$ and $\mathrm{X} 1=42$

data $(K)=1+3,3 \log n$

The sum of whole $\mathrm{N}=$ The number of data, $\log 29=1,46$ So, $P=\frac{84-42}{1+3,3 \log 29}=\frac{42}{1+4,81}=\frac{42}{5,81}=7$

From the table of formative test score interval and frequency above, the writer presented the data in histogram. 
KAIROS ELT JOURNAL, Vol. 1, No. 3, December 2017

Copyright $\odot 2017$, ISSN: 2580-4278

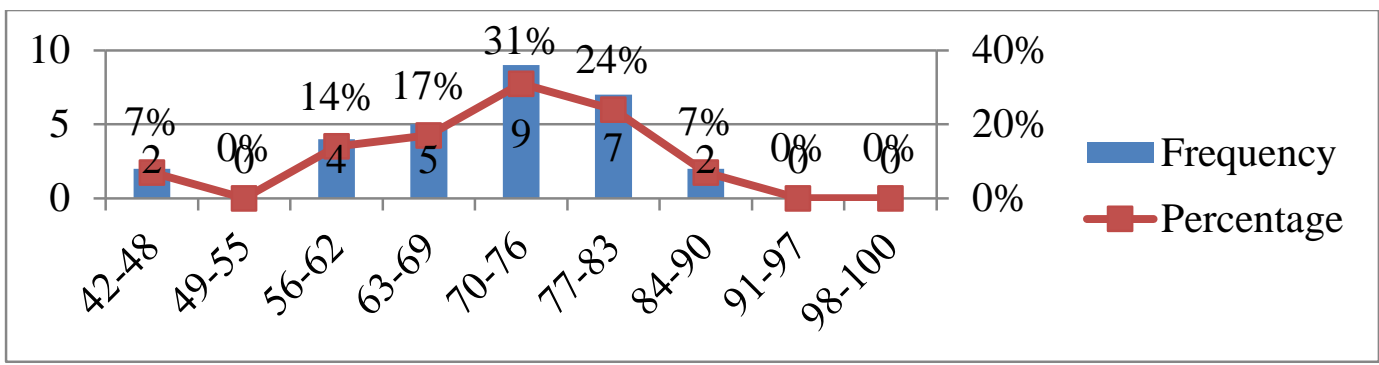

Figure 4.2: The Histogram of Formative Test

From the histogram of formative test, the highest score interval was 70 to 76 . It meant that there were (31\%) 9 students got the highest score in this interval. The lowest score interval were 49 to 55,91 to 97 , and also 98 to 100 , there was no student who got formative test score in this interval. In addition, there were (7\%) 2 students who got score formative test in interval 42 to 48 . Then, there were (14\%) 4 students who got score formative test in interval 56 to 62 . After that, there were (17\%) 5 students who got score formative test in interval 63 to 69 . There were $(24 \%) 7$ students who got score formative test interval 77 to 83 . Last, there were (7\%) 2 students who got score formative test interval 84 to 90 .

Students' Post-Test Score

Table 4.3 : Post-Test Score Interval

\begin{tabular}{lll}
\hline Score Interval & Frequency & Percentage \\
\hline $\mathbf{4 8 - 5 4}$ & 2 & $7 \%$ \\
\hline $\mathbf{5 5 - 6 1}$ & 1 & $3 \%$ \\
\hline $\mathbf{6 2 - 6 8}$ & 3 & $10 \%$ \\
\hline $\mathbf{6 9 - 7 5}$ & 2 & $7 \%$ \\
\hline $\mathbf{7 6 - 8 2}$ & 14 & $48 \%$ \\
\hline $\mathbf{8 3 - 8 9}$ & 5 & $17 \%$ \\
\hline $\mathbf{9 0 - 9 6}$ & 2 & $7 \%$ \\
\hline $\mathbf{9 7 - 1 0 0}$ & 0 & $0 \%$ \\
\hline Total & $\mathbf{2 9}$ & $\mathbf{1 0 0 \%}$ \\
\hline
\end{tabular}

Scoring interval is found by applying this following formula:

Scoring Interval $(P)=\frac{X n-X 1}{1+3,3 \log n}$

Where:

The division of distance $(\mathrm{R})=\mathrm{Xn}$ (the highest score) $-\mathrm{X} 1$ (the lowest score)

In which, $\mathrm{Xn}=90$ and $\mathrm{X} 1=48$

The sum of whole data $(K)=1+3,3 \log n$

number of data, $\log _{29}=1,46$

So, $\mathrm{P}=\frac{\mathrm{N}=\frac{90-48}{1+3,3 \log 29}}{\text { The }}$

$\frac{42}{1+4,81}=\frac{42}{5,81}=7$

From the table of formative test score interval and frequency above, the writer presented the data in histogram. 
KAIROS ELT JOURNAL, Vol. 1, No. 3, December 2017

Copyright@2017, ISSN: 2580-4278

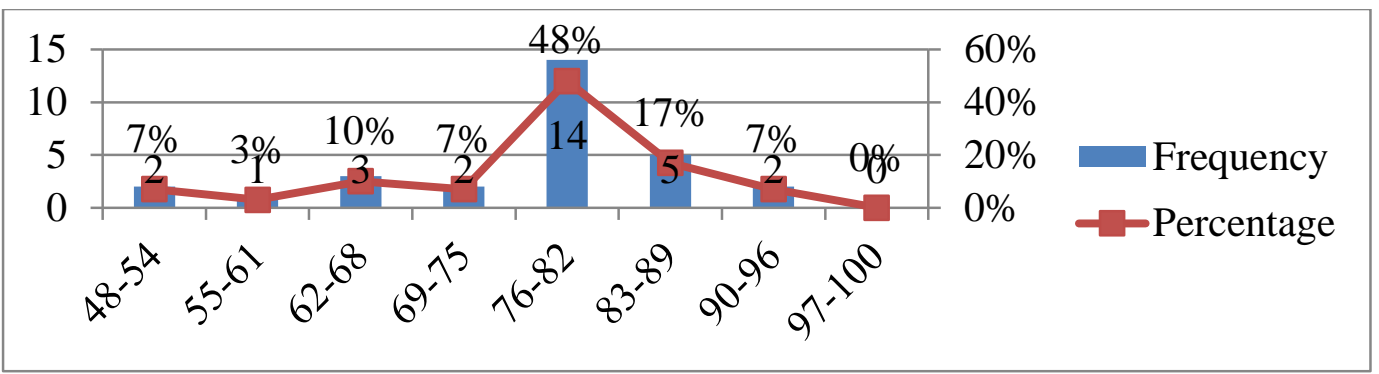

Figure 4.3 : The Histogram of Students' Post-Test

From the histogram of post-test, the highest score interval was 76 to 82 . It meant that there were (48\%) 14 students who got the highest score in this interval. The lowest score interval was 97 to 100 , there was no student who got post-test score in this interval. In addition, there were (7\%) 2 students who got score post-test in interval 48 to 54 . Then, there was (3\%) 1 student who got score post-test in interval 55 to 61 . After that, there were (10\%) 3 students who got score post-test in interval 62 to 68 . There were (7\%) 2 students who got score posttest in interval 69 to 75 . There were (17\%) 5 students who got score post-test in interval 83 to 89. And last, there were (7\%) 2 students who got score post-test in interval 90 to 96.

\section{Students' Mean Score}

The improvement of the students writing skill by Peer Review Strategy could also be seen from the mean of the students' score in pre-test, formative test, and post-test. Therefore, to know the improvement of all tests, the following formula was applied:

$\bar{x}=\frac{\sum \mathrm{x}}{\mathrm{N}}$

Where $\bar{x}=$ the mean of the students

$\sum \mathrm{x}=$ the total of score

$\mathrm{N}=$ the number of the students.

The writer presented the data of mean scoring through histogram. The histogram was presented as follows:

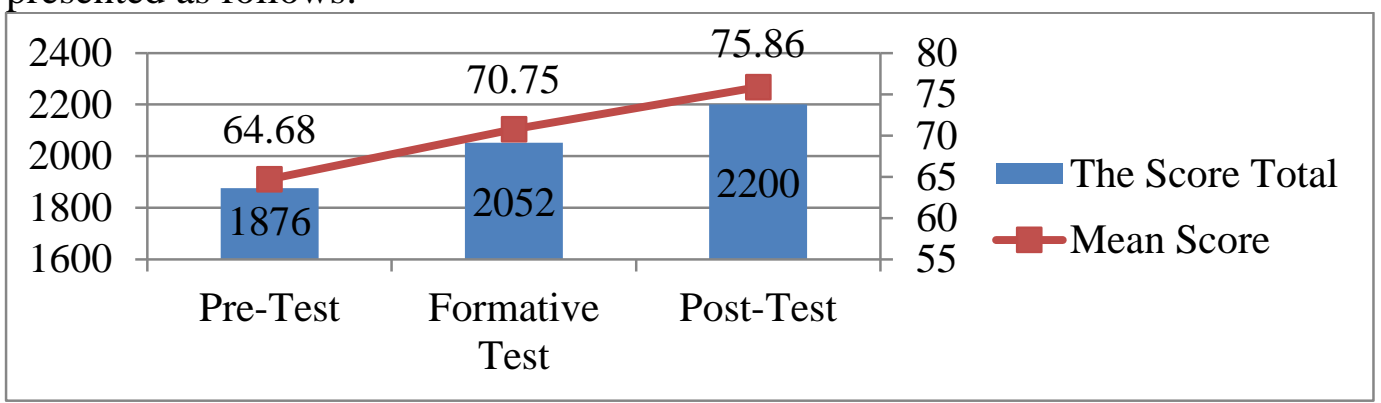

Figure 4.4 : The Histogram of Students' Mean Score

The improvement of the students' mean score kept increasing from pre-test, formative test until post-test. Based on the histogram, it can be seen that the mean score of the pre-test was 64,68 , the mean score of the formative test was 70,75, and the last, the mean score of the post-test was 75,86 . From the result of the students' mean score above, it can be concluded that the students' mean score improved. The increasing point from pre-test to post-test was 11,18. 
KAIROS ELT JOURNAL, Vol. 1, No. 3, December 2017

Copyright@2017, ISSN: 2580-4278

\section{Students' Score Based on KKM}

In this study, the writer also calculated it in the form of the percentage of scoring standard to know the total of the students who passed the KKM. The writer used the formula as follows:

$\mathrm{P}=\frac{\mathrm{F}}{\mathrm{N}} \times 100 \%$

The writer presented the students' data percentages who got the score $\geq 75$ through histogram. It was presented as follows:

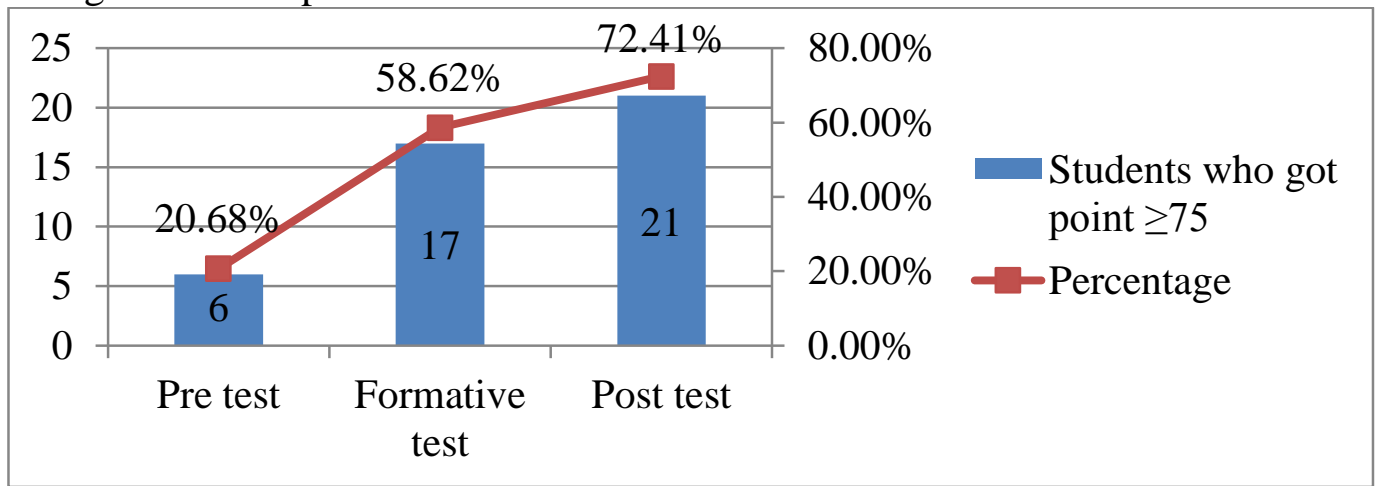

Figure 4.5 : The Histogram of Students' Percentages Based on $K K M \geq 75$

The percentage of students who got the score $\geq 75$ showed the improvement of students' score from the first test (pre-test) until the last test (post-test). The histogram above presented that the students' percentage who got score $\geq 75$. There was $20,68 \%$ (6 students) passed KKM in pre-test. In formative test, there was 58,62\% (17 students) passed KKM. Last, in post test, there was $72,41 \%$ (21 students) passed KKM and only 8 students were not passed KKM. It can be concluded that there was a significant improvement about $52 \%$ from pre-test to post-test.

\section{Students' Scoring Achievement}

The writer presented the table of quantitative data in both of cycle, as follows:

Table 4.4:The Quantitative Data

\begin{tabular}{llll}
\hline Component & Pre Test & $\begin{array}{l}\text { Formative } \\
\text { Test }\end{array}$ & Post Test \\
\hline Score & 1876 & 2052 & 2200 \\
\hline Mean & 64,68 & 70,75 & 75,86 \\
\hline Median & 64 & 76 & 78 \\
\hline Mode & 66 & 76 & 80 \\
\hline Students number who got $\geq \mathbf{7 5}$ & 6 & 17 & 21 \\
\hline Students percentage who got $\geq \mathbf{7 5}$ & $20,68 \%$ & $58,62 \%$ & $72,41 \%$ \\
\hline
\end{tabular}

Based on the table above, it can be seen that the mean score of pre-test, was 64,68. After the first cycle was conducted, there was improvement of mean score of formative test was 70,75. Then, there was also significant improvement in second cycle namely in post-test was 75,86 . It showed that the second cycle was better than first cycle. It can also be seen from the students' percentage who got score $\geq 75$. In the pre-test, there was $20,68 \%$ of students who got score $\geq 75$. After the first cycle was conducted, there was $58,62 \%$ of students who got score $\geq 75$ in formative test. And then, there was $72,41 \%$ of students who got score $\geq 75$ in post-test. In addition, there were median from the result of each test. In pre-test, the median score was 64 , in formative test was 76 , in the last test namely post-test was 78 . Not only median

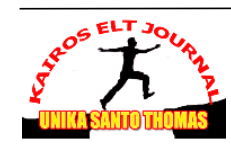


KAIROS ELT JOURNAL, Vol. 1, No. 3, December 2017

Copyright@2017, ISSN: 2580-4278

but the mode score also presented namely in pre-test, the mode score was 66, in formative test was 76 and in post-test was 80 . From the result above, it indicated that Peer Review Strategy was effective tool to improve the students' skill in writing recount texts. There was a progress about 11,18 based on the students' mean score and also about $51,73 \%$ based on the Mastery Minimum Criteria (Kriteria Ketuntasan Minimum (KKM)).

\section{The Qualitative Data}

The qualitative data were taken from observation sheet, field notes, and questionnaire and were presented below.

\section{Observation Sheet}

Observation sheet was focused on the situation of teaching learning process including the students' activities, behavior and interaction in the classroom. The observation sheet was made by the writer and it checked by the teacher who acted as the collaborator and observed the teaching learning process in the cycle 1 and cycle 2 . The complete data can be seen as follows:

\section{Table 4.5 Observation Sheet I Cycle I and Cycle II}

\begin{tabular}{|c|c|c|c|c|}
\hline $\begin{array}{l}\text { Peer } \\
\text { Review } \\
\text { Strategy }\end{array}$ & The Strategy Contribution & $\begin{array}{l}\text { Cycle } \\
\text { I } \\
(\sqrt{ })\end{array}$ & $\begin{array}{l}\text { Cycle } \\
\text { II } \\
(\sqrt{ })\end{array}$ & Notes \\
\hline $\begin{array}{l}\text { Step } \\
\text { One }\end{array}$ & $\begin{array}{l}\text { 1. Students are given the } \\
\text { explanation about procedure } \\
\text { of Peer Review Strategy }\end{array}$ & $\begin{array}{l}\sqrt{ } \\
\text { Yes }\end{array}$ & $\begin{array}{l}\sqrt{ } \\
\text { Yes }\end{array}$ & - \\
\hline $\begin{array}{l}\text { Step } \\
\text { Two }\end{array}$ & $\begin{array}{l}\text { 1. Students are asked to write } \\
\text { the first draft of recount texts } \\
\text { based on the topic }\end{array}$ & $\begin{array}{l}\sqrt{ } \\
\text { Yes }\end{array}$ & $\begin{array}{l}\sqrt{ } \\
\text { Yes }\end{array}$ & - \\
\hline \multirow[t]{3}{*}{$\begin{array}{l}\text { Step } \\
\text { Three }\end{array}$} & $\begin{array}{l}\text { 1. Students are asked to } \\
\text { conduct Peer Review in pairs } \\
\text { of student group, exchanging } \\
\text { their first draft one with } \\
\text { another }\end{array}$ & $\begin{array}{l}\sqrt{ } \\
\text { Yes }\end{array}$ & $\begin{array}{l}\sqrt{ } \\
\text { Yes }\end{array}$ & - \\
\hline & $\begin{array}{l}\text { 2. Each student read and } \\
\text { reviewed their partners' draft }\end{array}$ & No & $\begin{array}{l}\sqrt{ } \\
\text { Yes }\end{array}$ & $\begin{array}{lr}\begin{array}{l}\text { Only some } \\
\text { students read }\end{array} \\
\text { reviewed and } \\
\text { partners' draft }\end{array}$ \\
\hline & $\begin{array}{l}\text { 3. The teacher moving around } \\
\text { to check whether the Peer } \\
\text { Review Strategy is good } \\
\text { applied in learning writing }\end{array}$ & $\begin{array}{l}\sqrt{ } \\
\text { Yes }\end{array}$ & $\begin{array}{l}\sqrt{ } \\
\text { Yes }\end{array}$ & - \\
\hline \multirow[t]{2}{*}{$\begin{array}{l}\text { Step } \\
\text { Four }\end{array}$} & $\begin{array}{l}\text { 1. Students are asked to } \\
\text { deliver feedback and } \\
\text { suggestion on partners' paper }\end{array}$ & $\begin{array}{l}\sqrt{ } \\
\text { Yes }\end{array}$ & $\begin{array}{l}\sqrt{ } \\
\text { Yes }\end{array}$ & - \\
\hline & $\begin{array}{l}\text { 2. Students made comments } \\
\text { and suggestions after reading } \\
\text { their partners' paper }\end{array}$ & No & $\begin{array}{l}\sqrt{ } \\
\text { Yes }\end{array}$ & $\begin{array}{l}\text { Only some of } \\
\text { students who made } \\
\text { comment, feedback, } \\
\text { and suggestion on } \\
\text { their partners' paper } \\
\text { because they were } \\
\text { still confused of it }\end{array}$ \\
\hline
\end{tabular}


KAIROS ELT JOURNAL, Vol. 1, No. 3, December 2017

Copyright $\bigcirc 2017$, ISSN: 2580-4278

\begin{tabular}{|c|c|c|c|c|}
\hline & $\begin{array}{l}\text { 3. Students focus on writing } \\
\text { aspects namely content, } \\
\text { organization, vocabulary, } \\
\text { grammar, punctuation and } \\
\text { spelling (mechanics) }\end{array}$ & No & $\begin{array}{l}\sqrt{ } \\
\text { Yes }\end{array}$ & $\begin{array}{l}\text { Only some of } \\
\text { students understand } \\
\text { and focus on writing } \\
\text { aspects in applying } \\
\text { Peer Review }\end{array}$ \\
\hline $\begin{array}{l}\text { Step } \\
\text { Five }\end{array}$ & $\begin{array}{l}\text { 1. Students are asked to return } \\
\text { the first draft and guideline } \\
\text { sheets to the writer }\end{array}$ & $\begin{array}{l}\sqrt{ } \\
\text { Yes }\end{array}$ & $\begin{array}{l}\sqrt{ } \\
\text { Yes }\end{array}$ & - \\
\hline Step Six & $\begin{array}{l}\text { 1. Students are asked to } \\
\text { rewrite their recount text } \\
\text { based on their peer feedback }\end{array}$ & $\begin{array}{l}\sqrt{ } \\
\text { Yes }\end{array}$ & $\begin{array}{l}\sqrt{ } \\
\text { Yes }\end{array}$ & - \\
\hline
\end{tabular}

Table 4.6 Observation Sheet II Cycle I and Cycle II

\begin{tabular}{lllll}
\hline & \multicolumn{3}{l}{ Cycle I } & \multicolumn{2}{l}{ Cycle II } \\
\cline { 2 - 5 } CRITERIA & YES & NO & YES & NO
\end{tabular}

TEACHER

1. The teacher comes on time

2. The teacher is able to open the class well

\begin{tabular}{lll}
\hline 3. The teacher greets the students & $\checkmark$ & $\checkmark$ \\
\hline 4. The teacher asks the students condition and & $\checkmark$ & $\checkmark$
\end{tabular} their attendance list

5. The teacher explains the objectives of teaching

6. The teacher does brainstorming to introduce the topic

7. The teacher explains the material clearly

8. The teacher responds the students' questions and gives chance to all students to ask the topic

9. The teacher asked students to work in pairs of student group

10. The teacher manage time effectively and efficiently

\section{STUDENTS}

1. The students pay attention to the teacher's explanation

2. Students write the first draft of recount texts based on the topic

3. Students conduct Peer Review Strategy in pairs of student group

4. Students exchange their paper one with another

5. Students read and reviewed their partners' paper 
KAIROS ELT JOURNAL, Vol. 1, No. 3, December 2017

Copyright $\odot 2017$, ISSN: 2580-4278

\begin{tabular}{|c|c|c|}
\hline $\begin{array}{l}\text { 6. Student gave feedback, suggestions, or } \\
\text { comments on partners' paper after reading it }\end{array}$ & $\checkmark$ & $\checkmark$ \\
\hline $\begin{array}{l}\text { 7. Students were focused on writing aspects } \\
\text { such as organization, content, vocabulary, } \\
\text { grammar, punctuation and spelling }\end{array}$ & $\checkmark$ & $\checkmark$ \\
\hline $\begin{array}{l}\text { 8. Students gave partners' paper and peer } \\
\text { reviewer sheet to the own writer }\end{array}$ & $\checkmark$ & $\checkmark$ \\
\hline $\begin{array}{l}\text { 9. Students rewrited their recount texts based } \\
\text { on their peer feedback }\end{array}$ & $\checkmark$ & $\checkmark$ \\
\hline SITUATION & & \\
\hline $\begin{array}{l}\text { 1. The classroom is comfortable (clean, calm, } \\
\text { and organized) }\end{array}$ & $\checkmark$ & $\checkmark$ \\
\hline 2. The classroom is not noisy & $\checkmark$ & $\checkmark$ \\
\hline
\end{tabular}

\section{Field Notes}

In this study, the writer also used the field notes as the instrument of collecting the data during the teaching and learning process. The writer observed the activity of the students during the implementation of Peer Review Strategy and all the students' improvement in writing recount texts after implementing this strategy.

\section{Discussion}

Peer Review Strategy was applied to improve students' skill in writing recount texts at 8A of SMP Budi Murni 3 Medan. As the collaborator, the English teacher and the writer collaboratively discussed the result of the study. They concluded that the use of Peer Review Strategy could be the effective way to help students in writing the recount texts. It was shown in histogram 4.4, in which the mean score of each test improved. The mean score of pre-test was 64,68 , formative test was 70,75 , and the post-test was 75,86 . Those scores showed that the second cycle was better than the first cycle.

The improvement can be also seen from the percentage of students who got score $\geq$ 75 . In pre-test, there was $20,68 \%$ ( 6 students) who got score $\geq 75$, in formative test, there was $58,62 \%$ of students who got point $\geq 75$. And then, there was $72,41 \%$ of students who got point $\geq 75$ in post test. However, there was about $28 \%$ students were got point $\leq 75$. Besides that, the improvement can be seen in the observation sheet, field notes, and questionnaires. Most of the students were more active and enthusiastic during the process of teaching and learning that started from the first to second cycle when the strategy was applied.

In conclusion, Peer Review Strategy was suitable strategy to improve students' skill in writing recount texts because this strategy gave students a chance to think personally to create their own recount text. After that, the students were demanded to be more active so that they could review their partner' paper and gave correction, feedback or suggestion on paper which has function to improve students' writing skill in recount text. In this study, students were focused on generic structure, language features of recount texts. Therefore, they could understand more about recount texts and made their writing skill in recount texts improved. As the result, the students' score test improved in both of cycle after being taught Peer Review Strategy and also gave good responses and condition to all students in teaching learning writing recount texts. 
KAIROS ELT JOURNAL, Vol. 1, No. 3, December 2017

Copyright $\odot 2017$, ISSN: 2580-4278

\section{CONCLUSIONS}

After presenting and analyzing the data in the previous chapter, the writer draws the conclusions as follows:

1) The result of the study showed that Peer Review Strategy works effectively on improving students' skill in writing recount texts. The improvement could be seen from the students' mean score of pre-test was 64,68 , formative test was 70,75 and post-test was 75,86 . In addition, based on the Minimum Mastery Criteria showed that students' score of pre-test was $20,68 \%$ or only 6 students got score $\geq 75$, formative test was $58,62 \%, 17$ students got score $\geq 75$, and post-test was 72,41\%, 21 students got score $\geq 75$. In conclusion, Peer Review Strategy were suitable and beneficial strategy in improving students' skill in writing recount texts.

2) The students' responses were very good. They agreed with application Peer Review Strategy in teaching learning writing. They were more active and enthusiastic in learning writing recount texts after being taught by using Peer Review Strategy. It could be seen from the resut of qualitative data such as observation sheet, field notes and questionnaire during the study. In conclusion, Peer Review Strategy have good effects for students' learning behavior especially in learning writing recount texts.

\section{BIBLIOGRAPHY}

Arifiana, C. 2015. Improving Students'Skill in Writing Recount Text by Using Peer Review Technique of the eighth Grade Students of SMP Negeri 4 Batang, Central Java. Unpublished Sarjana's Thesis, Teachers Training and Education Faculty: State University of Semarang.

Anderson, M \& Anderson, K. 1997. Text Types in English. SouthYarra, VIC: Macmillan Education.

Breuch, L. A. K. 2004. Virtual Peer Review. New York: University of New York Press.

Brown, H. D. 2004. Language Assessment: Principles and Classroom Practices. New York: Pearson Education.

Byrne, D. 1988. Teaching Writing Skills. London: Longman.

Edge, J. 1989. Mistakes and Correction. London: Longman.

Emilia, E. 2011. Pendekatan Genre-Based dalam Pengajaran Bahasa Inggris: $\quad$ Petunjuk untuk Guru. Bandung: RIZQI Press.

Gerot, L. dan Wignell, P. 1994. Making Sense of Functional Grammar. Sydney: Gerd Stabler.

Godlee, F. \& Jefferson, T. 2003. Peer Review in Health Sciences. London: BMJ Books.

Graham, S. \& Perin, D. 2007. Writing Texts: Effective Strategies to Improve Writing of Adolescents in Middle and High Schools. New York: Alliance for Excellent Education. 
KAIROS ELT JOURNAL, Vol. 1, No. 3, December 2017

Copyright@2017, ISSN: 2580-4278

Harmer, J. 2004. How to Teach Writing. London: Longman.

2007. The Practice of English Language Teaching. Essex: Pearson Education Limited.

Hill, C. \& Parry, K. (Eds.). 1994. From Testing to Assessment: English as an International Language. London: Longman.

Hyland, K. 2003. Second Language Writing. New York: Cambridge University Press.

2004. Genre and Second Language Writing. Michigan: The University of Michigan Press.

Kemmis, S. \& Mc Taggart, R. 1988. The Action Research Planner $\left(3^{\text {rd }}\right.$ ed). $\quad$ Victoria: Deakin University.

Liu, J. \& Hansen, J. 2002. Peer Response in Second Language Writing Classrooms. Michigan: University of Michigan Press.

2005. Guiding Principles for Effective Peer Response. English Language Teaching Journal: Oxford University Press. 59 (1). 31- 38.

Meyers, A. 2005. Gateways to Academic Writing. New York: A Pearson Education.

Nasution, N. S. R. 2012. Improving Students' Writing Recount Achievement Through Peer Review Technique of SMA Negeri 21 Medan. Unpublished Sarjana's Thesis, Faculty of Languages and Arts: State University of Medan.

O’Malley, J. M \& Pierce, L.V. 1996. Authentic Assessment for English Language Learners. Practical Approaches for Teachers. London: Longman.

Pearce, J. et al. 2009. Involving Students in Peer Review: Case Studies and Practical Strategies for University Teaching. Melbourne: University of Melbourne. 